\title{
Mixed Method Study of the Evolution of Leadership Traits during a Leader- ship Experience
}

\section{Ms. Luisa Ruiz Mendoza, University of Texas - El Paso}

Luisa is a recipient of the Gates Millennium Scholarship since 2009. In May 2013, Luisa graduated from Texas A\&M University with a degree in Business Management. Then, in December 2014 she received a master's degree in Higher Education Administration from the University of Texas at El Paso (UTEP). Ms. Ruiz plans to pursue a doctorate degree in Educational Leadership and Foundations with a concentration in Engineering Leadership at UTEP. She would like to work on a case study to measure the learning outcomes of engineering students in the new Bachelor's of Science degree at UTEP, Engineering Education \& Leadership.

\section{Mr. Leonardo Orea-Amador, University of Texas - El Paso}

Leonardo is a research student dedicated to design, engineering, and entrepreneurship. He is an investigator for the Empathic Design Studio at the University of Texas at El Paso (UTEP) since August 2015.

Leonardo is working to obtain his master's degree in Systems Engineering at the University of Texas at El Paso where he also obtained his bachelors of science in Mechanical Engineering.

In 2014 he and his team were awarded first place with project, ProductivityPod, at the Paso del Norte Venture Competition (PDNVC), a local competition which gives the opportunity for young entrepreneurs to exhibit their business competencies.

Currently he is working on launching a new startup company which seeks to innovate certain aspects in the realm of wind energy and will be established at El Paso.

\section{Dr. Meagan R. Kendall, University of Texas - El Paso}

Dr. Meagan R. (Vaughan) Kendall received her PhD from The University of Texas at Austin where her research focused on the design of a low-cost, volume adjustable prosthetic socket. Now an Assistant Professor at The University of Texas at El Paso, she is helping develop a new Engineering Leadership Program to help students to bridge the gap between traditional engineering education and what they will really experience in industry. Her research interests span the areas of engineering education, biomechanics, and product design methodology. 


\title{
Mixed Method Study of the Evolution of Leadership Traits During a Leadership Experience
}

\begin{abstract}
The mission of the University of Texas at El Paso (UTEP) is to provide access and excellence in higher education to underserved student populations. An innovative educational experience was created for a group of students from the Engineering Education and Leadership (E-LEAD) Department to help further UTEP's mission. These students are pursuing a Bachelor of Science that seeks to accelerate the development of students as leaders with innovating mindsets, engineering problem solving skills, and business acumen. All students pursuing this degree are required to complete two for-credit professional practice experiences. Thus, an internship was tailored to give a group of students the opportunity to practice and develop the skills they are gaining outside of the traditional classroom setting.

The educational experience created was a leadership internship to support the Higher Opportunities Thrive (H.O.T.) Conference hosted at UTEP. The conference's primary goal is to expose middle and high school students living in public housing to higher education. The role of the E-LEAD undergraduates in the conference was to add engineering workshops to the conference curriculum.

During the spring 2015 semester, four sophomore E-LEAD students were recruited for the internship - two to prepare and implement workshops for middle school students and the other two for high school students. The E-LEAD students received training based on the engineering design process, mirroring its steps during the developing and teaching of the workshops. This training included presentations on: STEM related fields of study, how innovation is driven by diversity, and how to motivate low-income students to study different fields of engineering. The E-LEAD students were provided with minimal required material for each workshop and were given the freedom to choose the focus and content of the workshops. They presented the activities and workshops to the supervising graduate student (observer). Since the design of the conference was such that the same set of workshops were given during each week of the 4-week conference, the E-LEAD students were encouraged to continue innovating their workshops for each week of the conference.

The observer using a mixed method analysis to measure the application and development of engineering and leaderships skills gained in the classroom. The students completed a Leadership Practices Inventory (LPI) self-assessment before and after their internship. The LPI is based on 30 statements using a rarely-to-very-frequently 5-point scale (http://www.studentleadershipchallenge.com/Assessments.aspx). The observer evaluated the participants using the same method. The five leadership attributes assessed were Model (the Way), Inspire (a Shared Vision), Challenge (the Process), Enable (Others to Act), and Encourage (the Heart). A pre- and post-leadership experience interview was also conducted. At the end of
\end{abstract}


every week, the participants were interviewed and completed a Likert scale survey to evaluate their personal and team leadership performance.

The LPI showed that participants had a measured leadership appreciation which improved from 3.4 to 3.9 points in average score. Whereas the observer qualified their apparent leadership to improve from 2.1 to 4.4 points. The attributes with the greater improvements were Model, Inspire, and Challenge. Particularly, participants prominently improved their encouragement skills. Only the Challenge attribute displayed divergent improvements.

\section{Introduction}

Leadership traits are not always emphasized in the engineering curriculum of higher education institutions. Once in college, if a student starts an engineering program, leadership opportunities are typically only available through extracurricular activities or internships ${ }^{1}$. This is largely because traditional engineering programs are not able to accommodate specific courses that foster leadership traits in their degree plan. This lack of curriculum integration can often be attributed to the topic's perceived complexity and the growth in the number of required core courses that subsequently limits the number of elective courses that fit in a traditional degree plan $^{2}$. Nonetheless, leadership traits are relevant to the skills that engineering students should have in the global workplace ${ }^{3}$.

The University of Texas at E1 Paso (UTEP) identified this need for the integration of leadership traits in its engineering curriculum. UTEP's commitment to provide both access and excellence in education led to the development of the first Bachelor's of Science in Engineering Leadership (BSEL) ${ }^{4}$. Housed in the Engineering Education \& Leadership Department, the Engineering Leadership (E-LEAD) program focuses on accelerating student leadership development through activities integrated throughout the BSEL curriculum. The overall ELEAD approach to leadership development is practice based and seeks to build leadership skills by focusing on activities that foster the development of students' character, competence, and capacity (e-lead.utep.edu). Therefore, as a component of the BSEL, students are required to complete two for-credit professional practice experiences.

In summer 2015, an internship was tailored to give a group of E-LEAD students the opportunity to practice and perfect their growing leadership skills. The educational experience created was an internship to support the Higher Opportunities Thrive (H.O.T.) Conference funded by the Housing Authority of the City of El Paso (HACEP) hosted at UTEP (http://ia.utep.edu/Defaul.aspx?tabid=65572). Every year the conference's primary goal is to expose middle and high school students living in public housing to higher education. That summer, the conference was expanding its focus to include opportunities to introduce participants to the STEM fields. The role of the E-LEAD students was to facilitate the creation and delivery of new engineering workshops during the conference. Therefore, the internship provided an opportunity for E-LEAD students to practice a cyclic style of leadership emphasized 
in the E-LEAD program where students become better leaders by leading others and teaching them to subsequently lead other.

Other institutions also use internships as avenues for leadership development. For example, Penn State's Engineering Leadership Development Minor (ELDM) requires a leadership experience, where students are expected to observe, apply, and reflect upon topics covered academically ${ }^{5}$. The intent of this study, therefore, is to determine the level of leadership development students' benefit from during such an opportunity to practice their leadership skills integrated into their engineering curriculum.

\section{Method}

In the spring of 2015, four E-LEAD students were recruited for the internship with the H.O.T Summer Conference. The E-LEAD students were divided into pairs to prepare and implement workshops for local minority middle and high school students - one pair focused on the middle school program and the other on high school. The four male students were of Hispanic ethnicity and they had finished their first year in the E-LEAD program. One student was a senior in mechanical engineering but had recently transfer to the E-LEAD department. The other three E-LEAD students were freshman going into their sophomore year at the end of the internship. The E-LEAD students received training on the engineering design process and basic pedagogy by a member of the research team, also an author of the paper and graduate student in the UTEP's Leadership Higher Education Administration program (referred to here as the Observer). The training included readings, presentations, and individual research assignments on STEM related fields of study, how innovation is driven by diversity, and how to motivate lowincome students to study different fields of engineering.

Based on their training, the E-LEAD students were instructed to create appropriate activities for the STEM related workshops to be added to the H.O.T Conference. One activity developed was a team based project to build a battery powered robot. This activity was designed to teach the conference participants about the design process and how to work in teams. Another activity was to give the conference participants the opportunity to create something that could be used in their school, a new invention. Then participants were encouraged to facilitate a discussion where they described their invention and how it could be useful on their campus. The goal of these two projects focused on explaining why innovation is driven by diversity and the importance of teamwork. Successful completion of the projects by the participants was used as an indicator of how well they were able to understood and apply the material being delivered.

Before implementation that summer, all curriculum developed was presented to and practiced with the supervising graduate student. Since the design of the conference was such that the same set of workshops were given during each week of the 4-week conference, the E-LEAD 
students were instructed to continuously innovate and improve their workshops during each week of the conference. To do this, the students were encouraged to ask for feedback from conference participants, look at the artifacts created by conference participants, continue to conduct research on the given topics to develop new activities, plan new workshops, and reorder the activities as necessary. During the summer conference, the observer did not engage in the teaching of the workshop materials and restricted their involvement to observation and study data collection.

The development of leaderships skills gained by the E-LEAD students through the experience was evaluated using a mixed method approach. Pre- and post-leadership experience evaluation included an individual interview and a survey. For additional granularity, participants were also asked about their strategy for improvement on a weekly basis in a structured interview at the end of each week. The pre-, post-, and weekly individual interviews followed a uniform script. The same weekly interview script was used during the four weeks of the conference. The duration of the weekly interviews was approximately thirty minutes. One hour was designated for the pre- leadership experience interview as well for the post-leadership experience interview. The items of the interview were open ended questions. One category being evaluated in the weekly interview was individual and team leadership performance during the administration of the workshops and its activities. Another category evaluated was the difficulties encountered when facilitating the workshops and how the E-LEAD students surpassed them.

The observer transcribed the all of the interviews for detailed analysis. The observer knew the identity of the four E-LEAD students. The analysis of the data was done by comparing the leadership performance as an individual and as a team. Improvements in leadership performance were noted by comparing the weekly answers. The observer recorded the students' behavior, to identify any changes in leadership skills in the participants. Changes in behavior were also noted based on interview results. The first four questions of the end of the week interview measured on a Likert-scale the individual performance for each workshop of the week. Then, the last four questions asked the student to rate his team leadership performance.

The survey used before and after the leadership experience was the Leadership Practices Inventory (LPI) assessment tool ${ }^{6}$. The LPI consists of 30 statements which are scored using a rarely-to-very-frequently, 5-level Likert scale ${ }^{7}$. The LPI was the product of a qualitative study that seeks to identify behaviors, and not personality traits, of leaders. This framework was developed by Jim Kouzes and Barry Posner after interviews to more than 500 respondents. The LPI has a reliability that ranges between 0.75 and $0.95^{7}$. The LPI scores are unrelated to demographic characteristics. However, there is evidence that scores can be influenced by differences in groups ${ }^{8}$. 
The LPI assessment tool evaluates leadership through five leadership attributes: Model, Inspire, Challenge, Enable, and Encourage. In brief, Model the way is the ability of a leader to set the example by aligning actions with shared values. Inspire a shared vision enables the leader to enlist others in a common vision by appealing to shared aspirations. Challenge the process permits the leader to experiment and take risks by constantly generating small wins and learning from mistakes. Enable others to act serves to strengthen followers by sharing power and discretion. Encourage the heart is the attribute of recognizing contributions by showing appreciation for individual excellence ${ }^{6}$.

Both self and observer evaluations were completed for each E-LEAD student using the LPI tool. Provided that the data collected has a normal distribution, a t-test was utilized as the instrument to corroborate statistical significance between pre- and post- scores, as well as agreement between scores recorded by participants and observer.

\section{Results}

As described in the methods, the four E-LEAD students completed their training, developed curriculum, and implemented STEM related workshops for the H.O.T. Summer Conference. Data was collected as described using pre- and post-interviews and LPI surveys to document leadership development gains. In discussing their expectations for the experience during the Pre-leadership experience interview, the E-LEAD students expressed that they expected this experience to improve their leadership skills, that leading others would help them improve as leaders, to give them a chance to provide guidance to younger students, and to change the perspective low-income, first generation students have about STEM.

In the script of the weekly interviews E-LEAD students were asked to describe their personal leadership skills in which they wanted to improve for the following week and which was related to character, competence, and capacity (summary of weekly interview results available in Table 1). During the first week, with regards to competence, students reported the need to conduct further research on how to improve their workshops and activities. On capacity, the four E-LEAD students mentioned the desire to increase their adaptability and organizational skills in order. Then, in the third weekly interview the E-LEAD student 4 commented on the importance of character as it relates to leadership. He stated, "being a leader by example is a really big thing. I think that is why we can continue to work on building our character. When people get comfortable they forget that they can improve, therefore is important to continue to work on building your character."

Question five asked the students to describe the personal leadership skills that they would like to work on for the next week that would help them improve in the three pillars of the ELEAD program (character, competence, and capacity). The individual trend from week one to 
week four on the open ended answer to this question, shifted from attaining skills to build their competence and create better workshops, to gaining skills to build their capacity and, again, to adapt to the learning abilities of the H.O.T. conference participants. Question number eight asked the students to describe the strengths and weaknesses of his team during the implementation of the workshops with respect to the three pillars of the E-LEAD program. There was no difference in student responses to this question over the weekly interviews and students were focused on gaining skills related to competence.

Table 1. Summary of Weekly Interview Results for Student Self-Reflection on Leadership Performance.

\begin{tabular}{|c|c|c|c|c|}
\hline & Student 1 & Student 2 & Student 3 & Student 4 \\
\hline $\begin{array}{c}\text { Week } \\
1\end{array}$ & $\begin{array}{l}\text { 1. Being a role model } \\
\text { and leading by } \\
\text { example. } \\
\text { 2. Increased team work } \\
\text { and delegation of task } \\
\text { 3. Provided } \\
\text { participants a stronger } \\
\text { sense of belonging. }\end{array}$ & $\begin{array}{l}\text { 1. Stronger attitude to } \\
\text { encourage participants. } \\
\text { 2. Showed that from } \\
\text { failure we should learn } \\
\text { how to make things } \\
\text { better. } \\
\text { 3. Increased a stronger } \\
\text { leadership character }\end{array}$ & $\begin{array}{l}\text { 1. Applied better public } \\
\text { speaking skills } \\
2 \text {. Took charge over } \\
\text { challenges presented } \\
\text { 3. Met expectations of } \\
\text { participants }\end{array}$ & $\begin{array}{l}\text { 1. Applied better } \\
\text { communication skills } \\
\text { 2. Implemented better } \\
\text { organization skills } \\
\text { 3. Used of critical } \\
\text { thinking }\end{array}$ \\
\hline $\begin{array}{c}\text { Week } \\
2\end{array}$ & $\begin{array}{l}\text { 1. Applied new rules } \\
\text { 2. Increased creativity } \\
\text { by implementing a } \\
\text { reward system to retain } \\
\text { attention of } \\
\text { participants } \\
\text { 3. Interacted well with } \\
\text { participants }\end{array}$ & $\begin{array}{l}\text { 1. Implemented better } \\
\text { communication skills } \\
\text { 2. Increased team } \\
\text { collaboration } \\
\text { 3. Increased team work } \\
\text { and collaboration to re- } \\
\text { structured the } \\
\text { workshops to increase } \\
\text { participants interest }\end{array}$ & $\begin{array}{l}\text { 1. Improved on public } \\
\text { speaking skills } \\
\text { 2. Improved adaptability } \\
\text { skills when encountered } \\
\text { last minute changes in the } \\
\text { agenda } \\
\text { 3. Increased authority } \\
\text { role with participants to } \\
\text { managed the group } \\
\text { efficiently. }\end{array}$ & $\begin{array}{l}\text { 1. Got the message } \\
\text { across through the } \\
\text { activities by relating } \\
\text { the lessons to them } \\
\text { 2. Reinforced lessons } \\
\text { by asking questions } \\
\text { to review the material } \\
\text { 3. During the actives } \\
\text { helped participants to } \\
\text { keep in mind the goal } \\
\text { of the activities. }\end{array}$ \\
\hline $\begin{array}{c}\text { Week } \\
\mathbf{3}\end{array}$ & $\begin{array}{l}\text { 1. Improved lessons by } \\
\text { asking for feedback } \\
\text { from participants } \\
\text { 2. Learned to apply } \\
\text { feedback } \\
\text { 3. Revised the } \\
\text { workshops and } \\
\text { implement new } \\
\text { changes. }\end{array}$ & $\begin{array}{l}\text { 1. Learned to adjust to } \\
\text { change. } \\
\text { 2. Learned to Improvise. } \\
\text { 3. Receptive to change } \\
\text { in behavior of } \\
\text { participants. }\end{array}$ & $\begin{array}{l}\text { 1. Increased authority and } \\
\text { became strong of } \\
\text { character } \\
2 \text {. Worked closer with } \\
\text { team member to } \\
\text { implement changes in the } \\
\text { workshops due to last } \\
\text { minute changes in the } \\
\text { program agenda. }\end{array}$ & $\begin{array}{l}\text { 1. Increased } \\
\text { communication skills } \\
\text { 2. Increased } \\
\text { communication skills } \\
\text { 3.Became stronger in } \\
\text { character to project } \\
\text { more authority }\end{array}$ \\
\hline $\begin{array}{c}\text { Week } \\
4\end{array}$ & $\begin{array}{l}\text { 1. Inspired participants } \\
\text { during a workshop } \\
\text { 2. Increased } \\
\text { communication and } \\
\text { organization skills } \\
\text { 3. Learned to adapt to } \\
\text { change }\end{array}$ & $\begin{array}{l}\text { 1. Reflected on } \\
\text { strengths and } \\
\text { weaknesses } \\
\text { 2. Improved on } \\
\text { communication skills } \\
\text { 3. Increased confidence } \\
\text { for public speaking }\end{array}$ & $\begin{array}{l}\text { 1. Implemented activities } \\
\text { to increase participants' } \\
\text { confidence during the } \\
\text { workshop activities. } \\
\text { 2. Communicated } \\
\text { effectively with } \\
\text { participants. }\end{array}$ & $\begin{array}{l}\text { 1. Increased listening } \\
\text { skills } \\
\text { 2. Improved on time } \\
\text { management skills }\end{array}$ \\
\hline
\end{tabular}

In the pre-leadership experience students were asked to state what leadership skills they possessed. Student one stated, “I don't have those skills that I would like to have but along the 
way I know that I would gain some.” This same student in this post-leadership experience interview stated that "I have improved so much and I would not be in this position if it wasn't for E-LEAD program and with all the help of my peers and it helps people to get out of there comfort zone". In the pre-leadership experience interview student four stated that his definition of leadership was "how one deals with the ability to influence others". In the post- leadership experience he was asked how this definition of leadership changed and stated, "My definition change to a leader is someone who genuinely helps others at the best of his abilities and goes above and beyond in his capabilities to make a greater, fulfilling impact, while remaining humble." This demonstrates that the leadership internship experience not only improved their leadership skills but also changed their view of the skills that a leader should possess.

During the post-leadership experience interviews (summarized in Table 2), the participants expressed feelings of accomplishment when one of the H.O.T. conference participant demonstrated understanding of the concepts they taught and curiosity for different fields in engineering. In the fourth week, the E-LEAD students facilitated an activity where the H.O.T. conference participants had to play the role of a civil engineer, industrial engineer, and a mechanical engineer. The purpose of the activity was to foster teamwork but also find out if the conference participants understood what each field of engineering consisted of. At the end of the week, a female conference participant told an E-LEAD student that she wanted to become a Civil engineer to build bridges and roads in the community. This could have been a result of the awareness E-LEAD students raised about the different types of fields of engineering not only during one of the specific workshops, but over the entire week. The E-LEAD student 1 mentioned that his leadership confidence increased after learning the impact he had as a leader. He admitted that, prior to this experience, he thought leadership skills were gained only when placed in authoritative positions but now he had a better understanding that a leader is one who can guide others to lead. Then, he acknowledged that leadership skills are gained through teamwork, while having an impact on others, and learning to work with other's capabilities and character. He also said "I used to believe that a leader should not involve his feelings when leading others; that leaders only do whatever they have to do, without involving their personal beliefs. But, I realized that it is almost impossible to stay away from doing that. We learned so much from our students, that it was hard not to cry at the ceremonies when students were given the time to talk about their dreams and how this program helped them to believe in themselves. Also, I learned that as a leader sometimes you will be taken to places or situations where you do not want to be, or work with people you do not want to work." 
Table 2. Post Experience Leadership Interview Answer on Character, Competence, \& Capacity.

\begin{tabular}{|c|c|c|c|c|}
\hline & Student 1 & Student 2 & Student 3 & Student 4 \\
\hline $\begin{array}{l}\text { Character: who } \\
\text { you are as an } \\
\text { individual. } \\
\text { Personality, } \\
\text { values, and } \\
\text { conduct. } \\
\text { Liekert Question: } \\
\text { "My experiences } \\
\text { in this course } \\
\text { helped increase } \\
\text { my Character } \\
\text { Development." } \\
\text { How? }\end{array}$ & $\begin{array}{l}\text { It help me to } \\
\text { understand more } \\
\text { about myself and } \\
\text { my values that help } \\
\text { the kids understand } \\
\text { that you can } \\
\text { become that person } \\
\text { that you really are } \\
\text { and not someone } \\
\text { that you think you } \\
\text { are. }\end{array}$ & $\begin{array}{l}\text { I think this Hot } \\
\text { program helped me to } \\
\text { learn more about my } \\
\text { character. I learned that } \\
\text { we must support our } \\
\text { partner's decisions at } \\
\text { any given time. Of } \\
\text { course, it is hard } \\
\text { because everybody } \\
\text { sees different things, } \\
\text { but at the end, when } \\
\text { you are part of a team, } \\
\text { you must trust your } \\
\text { team members. }\end{array}$ & $\begin{array}{l}\text { This developed } \\
\text { my character } \\
\text { because it made } \\
\text { me become more } \\
\text { understanding and } \\
\text { flexible. }\end{array}$ & $\begin{array}{l}\text { I agree that my } \\
\text { experiences in this } \\
\text { program increased } \\
\text { my Character } \\
\text { Development by } \\
\text { allowing me to fill } \\
\text { the roles of a mentor, } \\
\text { peer-leader, and team } \\
\text { member all at the } \\
\text { same time. Therefore, } \\
\text { it was logical for me } \\
\text { to grow as an } \\
\text { individual to fulfill } \\
\text { all of these positions } \\
\text { with finesse. }\end{array}$ \\
\hline $\begin{array}{l}\text { Competence: } \\
\text { what you know. } \\
\text { Elevated subject } \\
\text { mastery. } \\
\text { Question: "My } \\
\text { experiences in } \\
\text { this course helped } \\
\text { increase my } \\
\text { Competence." } \\
\text { How? }\end{array}$ & $\begin{array}{l}\text { It has help me on } \\
\text { how much I really } \\
\text { know about } \\
\text { engineering and the } \\
\text { study on how things } \\
\text { work and know } \\
\text { more on the subject } \\
\text { that we are working } \\
\text { on }\end{array}$ & $\begin{array}{l}\text { It was a great } \\
\text { opportunity to } \\
\text { challenge our } \\
\text { competence. We did } \\
\text { not know what to } \\
\text { expect. We work for } 6 \\
\text { months with Luisa } \\
\text { Ruiz, and she gave us a } \\
\text { description about the } \\
\text { program, and how } \\
\text { students will behave. } \\
\text { But when the first day } \\
\text { started, it was } \\
\text { something else, we } \\
\text { faced so many } \\
\text { difficulties; nerveless, I } \\
\text { think we did a good job } \\
\text { showing what we have } \\
\text { learned in the E-lead } \\
\text { and showing our } \\
\text { competence to face any } \\
\text { challenge. }\end{array}$ & $\begin{array}{l}\text { This helped me in } \\
\text { the field of } \\
\text { competence } \\
\text { because I had to } \\
\text { complete tasks and } \\
\text { be adaptable to } \\
\text { situations } \\
\text { that were } \\
\text { unexpected, but I } \\
\text { was able to } \\
\text { complete the tasks } \\
\text { that were given to } \\
\text { me. }\end{array}$ & $\begin{array}{l}\text { I agree that my } \\
\text { experiences in this } \\
\text { course have helped } \\
\text { increase my } \\
\text { Competence by } \\
\text { pushing me to } \\
\text { conduct further } \\
\text { research in } \\
\text { innovation driven by } \\
\text { diversity and the } \\
\text { various fields of } \\
\text { engineering. Also, by } \\
\text { putting together tours } \\
\text { of the College of } \\
\text { Engineering for the } \\
\text { students, I gained a } \\
\text { broader knowledge } \\
\text { about the college } \\
\text { itself. }\end{array}$ \\
\hline $\begin{array}{l}\text { Capacity: What } \\
\text { you can } \\
\text { accomplish. } \\
\text { Question: "My } \\
\text { experiences in } \\
\text { this course helped } \\
\text { increase My } \\
\text { Capacity." How? }\end{array}$ & $\begin{array}{l}\text { My experience has } \\
\text { grown more on my } \\
\text { capacity side } \\
\text { because I know that } \\
\text { right know I can } \\
\text { accomplish } \\
\text { anything that I have } \\
\text { started just keep } \\
\text { moving and do } \\
\text { more through the } \\
\text { next couple of years }\end{array}$ & $\begin{array}{l}\text { My capacity was } \\
\text { developed as the weeks } \\
\text { were passing by, I find } \\
\text { out a better way how to } \\
\text { explain the workshops, } \\
\text { see what they like and } \\
\text { how to get them } \\
\text { focused on our } \\
\text { workshops. Also, the } \\
\text { capacity to understand } \\
\text { other supervisor, } \\
\text { understand their point } \\
\text { of view and why they } \\
\text { were asking us to do a } \\
\text { better job. }\end{array}$ & $\begin{array}{l}\text { This did help } \\
\text { increase my } \\
\text { capacity because I } \\
\text { would take on } \\
\text { more task than I } \\
\text { normally would } \\
\text { and be able to } \\
\text { complete them } \\
\text { effectively. }\end{array}$ & $\begin{array}{l}\text { I greatly agree that } \\
\text { my experiences in the } \\
\text { H.O.T. internship } \\
\text { helped increase my } \\
\text { capacity, or what I } \\
\text { can accomplish, by } \\
\text { allowing me to gain } \\
\text { courage and } \\
\text { understanding of the } \\
\text { influence I can have } \\
\text { on others. }\end{array}$ \\
\hline
\end{tabular}


To measure changes in leadership as a result of the experience, average LPI scores from before and after the experience were calculated for each E-LEAD student. These scores were calculated from the responses from both the self and observer survey results (Figure 1).

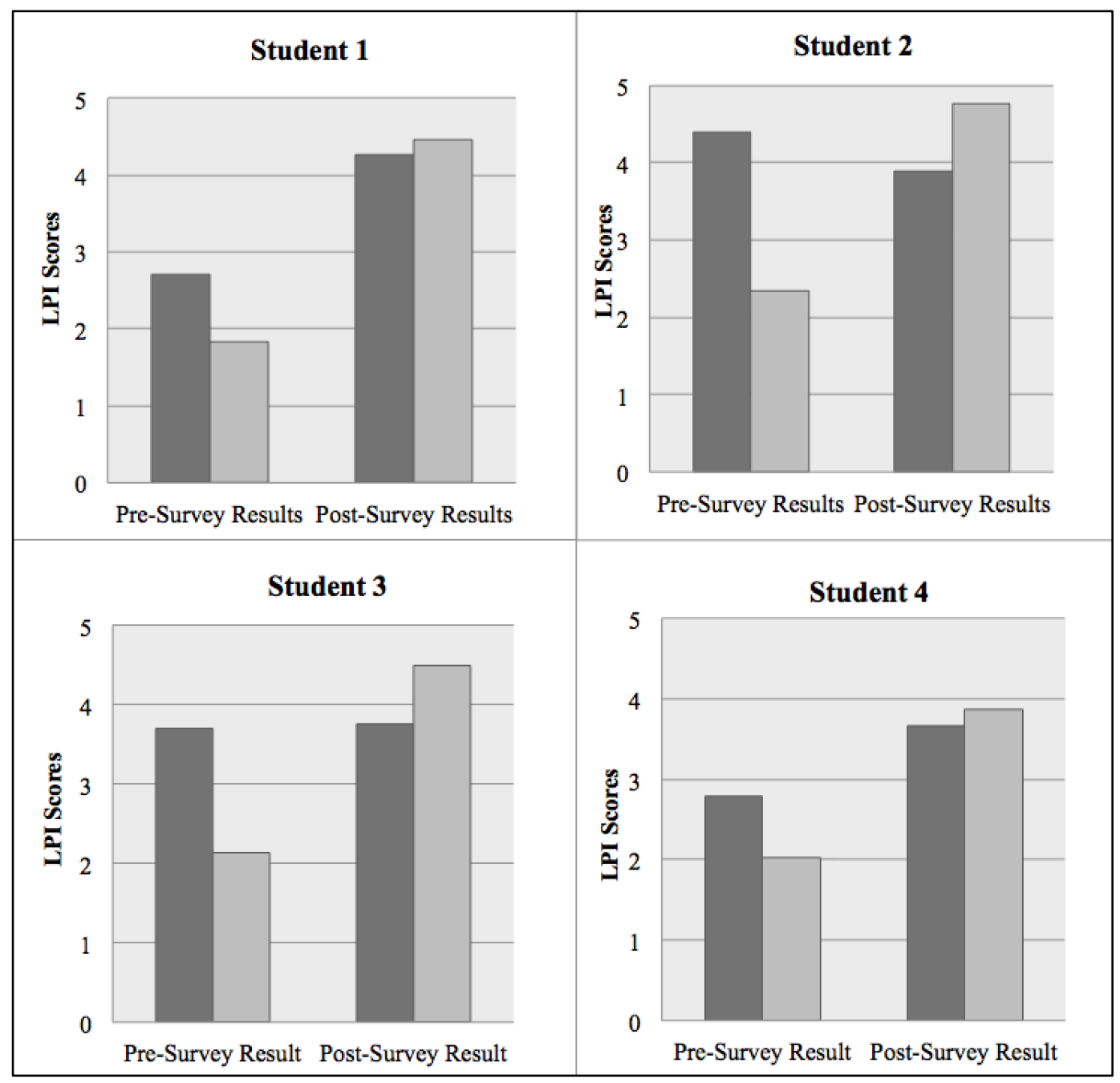

Figure 1. Average LPI Scores of E-Lead Students

In the average result for all four participants before and after, the observer rated the participants as having improved by 2.3 (STD .930) points, a statistically significant change $(\mathrm{p}<0.001$, paired t-test). However, when considering student's overall self-assessment scores, only Student 1 and 4 rated themselves as having improved (1.5 points change up from 2.7, $\mathrm{p}<0.001$, paired t-test and 0.9 points change up from $2.8, \mathrm{p}<0.001$, paired $t$-test). Student 2 actually rated himself as having diminished his leadership skills ( -0.5 points change down from 4.4, $\mathrm{p}<0.01$, paired t-test) while Student 3 noted no change ( 3.7 to $3.76, \mathrm{p}<0.73$, paired t-test). When calculating the overall score including self and observer assessments together for all ELEAD students, there is an improvement of 1.4 points ( $\mathrm{p}<0.001$, paired $\mathrm{t}$-test) as a result of the leadership experience. 
In addition to overall changes in leadership, changes in scores of the five leadership attributes (Model, Inspire, Challenge, Enable, and Encourage) were also calculated. LPI scores corresponding to these categories, as indicated by the survey, were again averaged for both self and observer responses. Figure 2 on the following page, shows a comparison between the average scores of participants and observer by category and their improvement respectively.

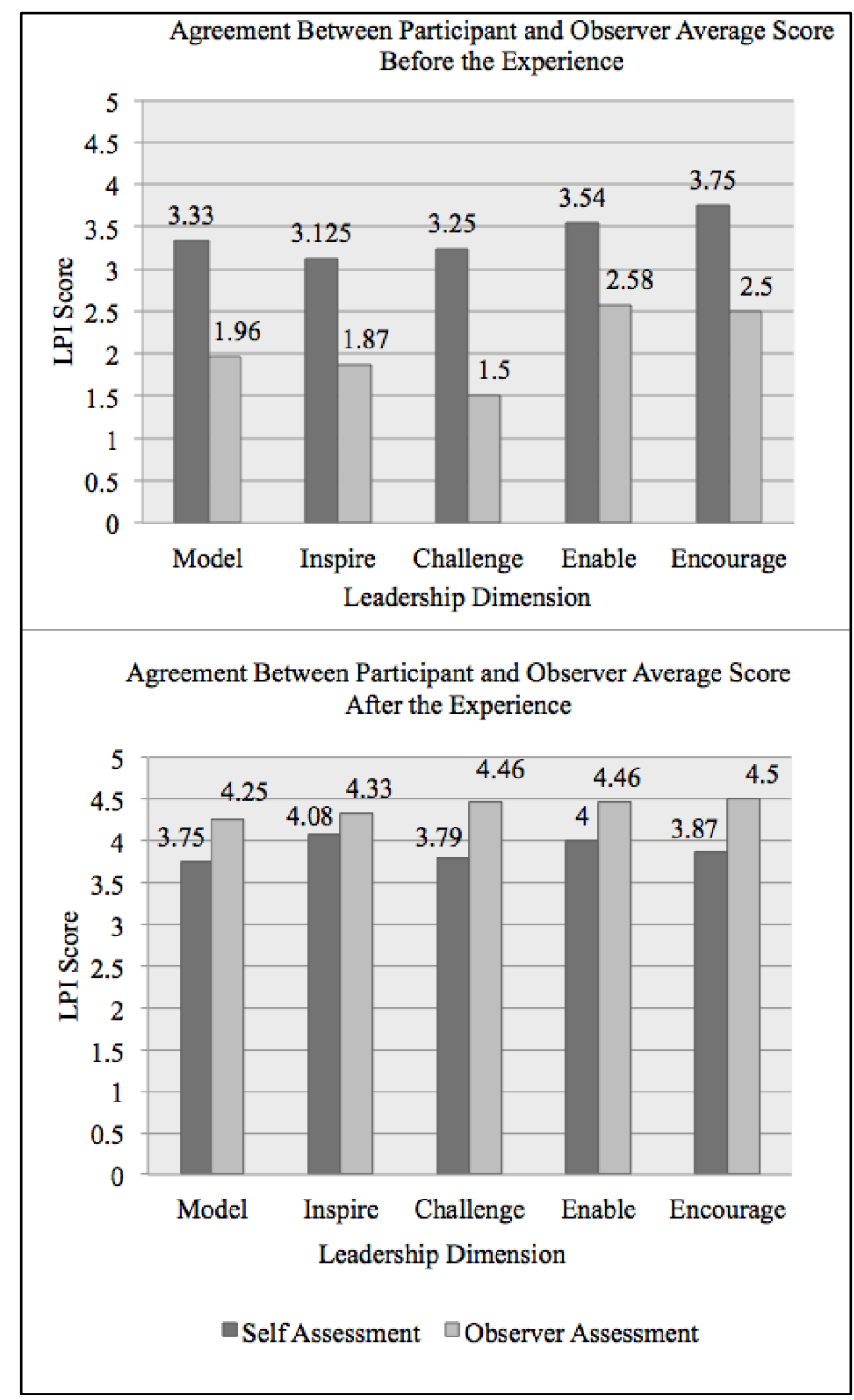

Figure 2. Comparison Between Average scores of Participants and Observer Before and After the Experience by Leadership Category.

On average, E-LEAD students rated themselves with non-statistically significant, minimal improvements in the areas of Model ( 0.4 points, $p<0.172$, paired t-test), Challenge ( 0.5 points, $\mathrm{p}<0.130$, paired t-test), Enable ( .5 points, $\mathrm{p}<0.159$, paired t-test), and Encourage (0.1 
points, $\mathrm{p}<0.694$, paired t-test). Only Inspire ( 0.9 points, $\mathrm{p}<0.004$, paired t-test) was presented as a statistically significant figure. In contrast, the observer rated the participants as having significantly improved in the areas of Model (2.3 points, $\mathrm{p}<0.001$, paired t-test), Inspire (2.5 points, $\mathrm{p}<0.001$, paired t-test), Challenge (2.9 points, $\mathrm{p}<0.001$, paired t-test), Enable (1.9 points, $\mathrm{p}<0.001$, paired t-test), and Encourage (2.0 points, $\mathrm{p}<0.001$, paired t-test).

In regards to agreement between the self and observer assessments, Figure 2 also shows that, during the beginning of the experience, there is a substantial difference between the scores recorded by the observer and the participants; Model (1.37, $\mathrm{p}<0.001$, paired t-test), Inspire (1.25, $\mathrm{p}<0.003$, paired t-test), Challenge (1.75, $\mathrm{p}<0.001)$, Enable $(0.96, \mathrm{p}<0.003)$, and Encourage (1.25, $\mathrm{p}<0.001)$. However, in the second survey at the end of the experience, this difference in agreement was significantly reduced as shown in the averages of the categories; Model $(0.50$, $\mathrm{p}<0.03)$, Inspire (0.25, $\mathrm{p}<0.207)$, Challenge (0.67, $\mathrm{p}<0.004)$, Enable $(0.45, \mathrm{p}<0.038)$, and Encourage $(0.65, \mathrm{p}<0.010)$.

When averaging the scores of all participants and observer together by leadership category (illustrated in Figure 3), participants improved by 1.4 points in Model $(p<0.001$, paired t-test), 1.7 points in Inspire ( $<<0.001$, paired t-test), 1.75 points in Challenge $(p<0.001$, paired ttest), 1.16 points in Enable ( $\mathrm{p}<0.001$, paired $t$-test), and 1.1 points in Encourage $(\mathrm{p}<0.001$, paired t-test).

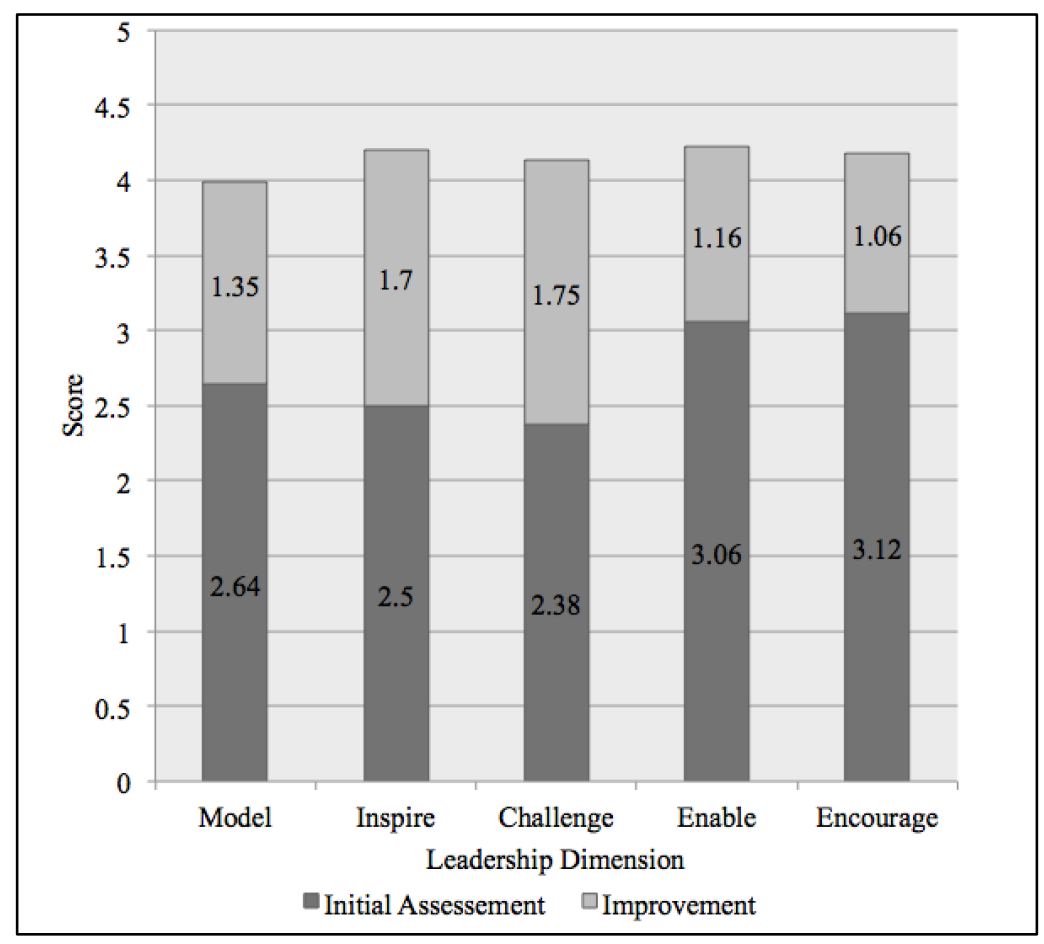

Figure 3. Global Improvement in the Five Leadership Dimensions 


\section{Discussion}

Both the results from LPI surveys and interviews demonstrated an overall increase in the students' leadership skills as a result of the leadership experience. In regards to the LPI survey, the final scores of both E-LEAD students and observer came to an average of 4.1 (0.79 STD) after the experience, up from 2.74 (1.39 STD). This increase is likely due to a gain in knowledge and experience of the E-LEAD students. It should be noted that none of the E-LEAD students claimed to have attained a perfect score of 5-Frequent overall in the areas that have been studied neither was it witnessed by the observer. Due to the observational nature of the study, a consistent lack of perfectionism in the behavior of the E-LEAD students had been anticipated. This may be related to the fact that the internship was provided as an environment to let the students develop and display their own level of leadership as opposed to acting as an educational mechanism that specifically encourages acquiring the leadership behaviors in question. Other than what could be inferred from the LPI survey questions, the students were not informed until after the study what areas of leadership were being specifically assessed nor were they given targeted training.

In assessing the five areas of leadership using the LPI survey, the categories of Challenge and Inspire saw the biggest improvement during the study (up 1.7 and 1.75 average score). Model, Enable, and Encouragement, on the other hand, had only mild improvements (up 1.35, 1.16 , and 1.06 average score respectively). This difference in improvement may be related to the complexity of each area. Challenge and Inspire are basic leadership traits that can be attained by simply showing adherence to a consistent and organized work plan that was emphasized during the planning and execution of the workshops. Whereas the other three attributes are more advanced leadership traits in which the leader needs to develop empathy for the specific needs of the followers and recognize their individual weaknesses, opportunities, contribution, and potential. These last three attributes can provide a glimpse to the level of maturity of the participant's leadership skills.

While the overall average of scores show an improvement in leadership skills, there is a marked disagreement between the observer and self-assessment in the initial LPI survey results (1.3 points average difference at the preliminary survey). This discrepancy becomes smaller in the second survey ( 0.5 points average difference). This discrepancy could very well be the results of an inflated sense of personal leadership capabilities felt by the students that corrected itself by the end of the experience. Towards the end, the scores of both participants and observer converged around a grade of 4 to 4.5 .

It could be argued that by the end of the experience both observer and students converged on a similar framework of leadership. It is also remarkable that even though the observer shows in her scores a much higher improvement, she also recorded scores much lower at the beginning. Likewise, participants showed a smaller improvement and reported a higher score at the 
beginning. For example, examining the particular student that reported a decrease in leadership we see that this student had an initial average score of 4.5 while during the second assessment he came down to 4.0 points. Similarly, the student that self-reported the biggest improvement of 1.5 points came up from 2.7 points to 4.2 . This same pattern is visible in the scores of the observer converging on an average of 4.4. Therefore, a gain in understanding in this leadership framework demonstrates that there was an improvement in skills and this improvement is reflected in the behavior of the participants as witnessed by the observer.

The results of the pre- and post- interviews demonstrated that the students' application of self-evaluation and intentional effort to improve their leadership performance helped them acknowledge the learning outcomes from their degree. The E-LEAD program emphasis of leadership as a cycle, for instance, was evident in the students' assessment of their leadership. When analyzing their performance, the students based their success as leaders on the impact they could see that they had on the conference participants.

\section{Limitations}

One limitation of the study was the time of the interviews. Some of the weekly interviews were conducted at the end of the day on Fridays. However, due to time conflict for some of the E-LEAD students one of the weekly interviews was conducted on a Friday morning for Student 2. In addition, this study follows a small number of students through a 4 week leadership experience. Future studies should incorporate a greater number of students over a variety of extracurricular leadership experiences.

In future research endeavors, additional insight into student leadership development could be garnered from having the participating students also assess the leadership development of their peers - rather than just self and observer assessment. Not only would this provide the students additional training in peer leadership assessment, it would also provide a deeper understanding of the individual student development.

\section{Conclusion}

The results of the leadership performance that E-LEAD students had during the development and implementation of the workshops revealed the innovation, leadership skills, and adaptability expertise learned in the BSEL degree. Participants were able to improve their leadership skills after applying their theoretical knowledge during an extracurricular leadership experience. This study demonstrates that a real-world experience helped individuals attain an improved aptitude for leadership, even when their educational understanding and training remained similar to that from before the experience. When E-LEAD students were exposed to a real life scenario where they had to be the leaders, they were empowered and demonstrated their learning outcomes from their degree. A leadership assessment reveals a statistically significant 
overall improvement of 1.4 points in a scale of 5 . There is a notable disparity of both assessments with the observer reported an improvement of 2.8 points while the students reported moderate or no improvements. This difference also becomes apparent when further analyzing the components of the assessment. The final scores of the assessment converge into a score of 4.0 to 4.4. The measured leadership behavior dimensions of Challenge and Inspire displayed the greatest impact compared to the other three dimensions of Model, Enable, and Encourage. These two dimensions may, therefore, be the first to develop due to their influence in the aspiration of the individual to become a leader. The other three traits may be skills more related to background knowledge than to actual experience. This demonstrates an intermediate level of leadership skills maturity. The sample of the study was arguably small due to the program's restrictions, but the intent is to continue the study and increase the sample size. The first year of the study was essentially evaluating a pilot program. This study can be applied for a broader engineering education audience that would like to test the application of leadership skills in their curriculum. The E-LEAD curriculum prepares its students to have a better understanding of leadership traits that they need to put in practice in their undergraduate degree. The E-LEAD students took the internship experience as the opportunity to put in practice what they had learned in their classroom. They did not think of the internship experience as the opportunity to learn leadership traits. Their main concerned throughout their leadership experience was to improve every week on their leadership skills. Overall, the leadership experience allowed students to put in practice their leadership traits and grown in the areas they identify they needed to improve.

\section{References}

1. Schuhmann, R. J. (2010). Engineering Leadership Education--The Search for Definition and a Curricular Approach. Journal of STEM Education: Innovations and Research, 11(3-4), 61-69.

2. Hartmann, B. L., \& Jahren, C. T. (2015). Leadership: Industry Needs for Entry-Level Engineering Positions. Journal of STEM Education: Innovations and Research, 16(3), 13-19.

3. Cox, M. F., Cekic, O., \& Adams, S. G. (2010). Developing Leadership Skills of Undergraduate Engineering Students: Perspectives from Engineering Faculty. Journal of STEM Education: Innovations and Research, 11(3-4), 22-33.

4. Gonzalez, V. Roger. et. al. (2015). Engineering Leadership: A new Engineering Discipline, Paper \#26.635.1. ASEE PEER. Seattle, Washington.

5. Crumpton-Young, L., McCauley-Bush, P., Rabelo, L., Meza, K., Ferreras, A., Rodriguez, B., \& ... Kelarestani, M. (2010). Engineering Leadership Development Programs a Look at What Is Needed and What Is Being Done. Journal of STEM Education: Innovations and Research, 11(3-4), 10-21.

6. Kouzes, J., and Posner, B. (2006). Leadership Practices Inventory® (LPI®), a 360-degree assessment tool. 
7. The Student Leadership Challenge, Second Edition. Retrieved from http://www.studentleadershipchallenge.com/Book/book--the-student-leadership-challenge-second-edition.aspx

8. The Leadership Practices Inventory: Theory and Evidence Behind the Five Practices of Exemplary Leaders. (2002). Retrieved from http://www.leadershipchallenge.com/UserFiles/lc_jb_appendix.pdf 